\title{
siRNA Delivery Systems in Cancer Therapy
}

\author{
Hossein Hosseinkhani* \\ Innovation Center for Advanced Technology, Matrix, USA
}

Submission: August 24, 2020; Published: September 14, 2020

"Corresponding author: Hossein Hosseinkhani, Innovation Center for Advanced Technology, Matrix, Inc., New York, NY 10029, USA

Abstract

Drug delivery systems (DDS) have shown great promise in delivery of drugs and genetic materials or pharmaceuticals and other xenobiotics to their site of action within an organism and eliminate the side effect and enhance the therapeutic effects of the drugs at exact delivery position. Small interfering RNA (siRNA) is a class of nucleic acid-based drugs able to suppress gene expression by interaction with mRNA before its translation. The primary success of siRNA delivery greatly depends on suitable vectors to deliver therapeutic genes. The main problems in the delivery of siRNA-based drugs for therapeutic use are the low efficiency of siRNA delivery to target cells and tissues. This review articles discusses the recent technology of siRNA delivery systems using new biomaterials and nanoparticles.

\section{Recent Technology of siRNA Delivery System}

Small interfering RNAs (siRNA) has been used extensively in blocking various genes and is presently being evaluated as a therapeutic for cancer and viral disease. RNA interference was first identified as a defence mechanism against the invasion of foreign genes in the nematode Caenorhabditis elegans and had subsequently been discovered in diverse eukaryotes such as fungi, insects, plants, and vertebrates. Researchers demonstrated that synthetic siRNAs were able to induce RNAi in mammalian cells. RNAi could affect gene silencing through chromatin remodeling, blocking protein synthesis and cleaving specifically targeted mRNA.

RNAi gene-silencing is dependent on the structure of the initiating RNA such as complete (siRNA) or incomplete (miRNA). These double stranded RNAs were processed by RNase III endonuclease enzyme called Dicer, which produces duplexes of approximately 21 nucleotides. After the action of Dicer, guide strand (one of the two strands of each fragment), were incorporated into the RNA induced silencing complex. Chemical modification of the phosphonothioate linkage had been used as a simple and effective method to increase the nuclease resistance of siRNA [1]. Other methods employed for the enhancement of siRNA stability in biological fluids including modification of the $2^{\prime}$-hydroxyl group of the pantone sugar, such as $2^{\prime}$-O-methyl or a methylene linkage between the $2^{\prime}$ and $4^{\prime}$ positions of the ribose [2].
It is becoming clear that due to its instability and degradability, naked siRNA is rarely applied in systemic delivery accordingly; this section will deal primarily with siRNA-loaded carriers, such as nanospheres, nanocapsules, liposomes, micelles, microemulsions, conjugates, and other nanoparticles. Polymeric biomaterials are classically biodegradable and positively charged (e.g., cationic cell penetrating peptides, cationic polymers, dendrimers, cationic lipids etc.) that are widely used as drug (gene, growth factor) carrier [3-20].

Conjugation of siRNA with a variety of small molecules (e.g., cholesterol, bile acids, and lipids), polymers, peptides, proteins (e.g., antibodies), as well as aptamers (e.g., RNAs), and encapsulating siRNA in nanoparticulate formulations improves the stability, cellular internalization, or cell-specific active targeted delivery synthetic polymers which have been widely investigated for siRNA delivery. These synthetic polymers may enhance intracellular delivery by facilitating endosomal escape and inducing lysosomal disruption, endosomal release, and siRNA protection from lysosomal degradation by way of buffering the endosomes [21-30]. Biodegradable polymers have been reported that they are enabling to undergo hydrolytic degradation, yielding non-toxic and neutral $\mathrm{pH}$ degradation products, thereby providing sustained gene delivery [31-45].

Therapies based on siRNA are entering clinics, especially for diseases requiring locoregional treatments, including age-related 
macular degeneration, diabetic macular edema, respiratory virus infection, pachyonychia congenital, hepatitis, human immunodeficiency virus infection, and cancer. There are several obstacles and concerns that should be overcome before RNAi will be used as a new therapeutic technique.

\section{Conclusion}

Although progress has been made in the field of siRNA delivery systems, there are several obstacles and concerns to be overcome before this new drug could be used as a new therapeutic agent. Several strategies need to minimize off-target effects, avoiding immune responses, increasing resistance to nuclease degradation and effective in delivery of siRNA to the appropriate cells or tissues by manipulating biopharmaceutical properties.

\section{References}

1. Hall AH, Wan J, Shaughnessy EE, Ramsay Shaw B, Alexander KA (2004) RNA interference using boranophosphate siRNAs: structure-activity relationships. Nucleic Acids Res 32: 5991-6000.

2. Dowler T, Bergeron D, Tedeschi AL, Paquet L, Ferrari N, et al. (2006) Improvements in siRNA properties mediated by $2^{\prime}$-deoxy-2'-fluorobeta-D-arabinonucleic acid (FANA). Nucleic Acids Res 34: 1669-1675.

3. Mahmoudi M, Hosseinkhani H, Hosseinkhani M, Boutry S, Simchi A, et al. (2010) Magnetic resonance imaging tracking of stem cells in vivo using iron oxide nanoparticles as a tool for the advancement of clinical regenerative medicine. Chem Rev 111: 253-280.

4. Mottaghitalab F, Rastegari A, Farokhi M, Dinarvand R, Hosseinkhani H, et al. (2017) Prospects of siRNA applications in regenerative medicine. Int J Pharm 524: 312-329.

5. Abedini F, Hosseinkhani H, Ismail M, Chen Y R, Omar A, et al. (2011) In vitro intracellular trafficking of biodegradable nanoparticles dextranspermine in cancer cell lines. Int J Nanotec 8: 712-723.

6. Abedini F, Ismail M, Hosseinkhani $\mathrm{H}$, Ibrahim TAT, Omar AR, et al (2011) Effects of CXCR4 siRNA/dextran-spermine nanoparticles on CXCR4 expression and serum LDH levels in a mouse model of colorecta cancer metastasis to the liver. Cancer manag Res 3: 301.

7. Abedini F, Ismail M, Hosseinkhani H, Omarb A, PeiPei C, et al. (2010) Toxicity evaluation of dextran-spermine polycation as a tool for genetherapy in vitro. J Cell Anim Biol 4: 170-176.

8. Azzam T, Eliyahu H, Shapira L, Linial M, Barenholz Y, et al. (2002) Polysaccharide-oligoamine based conjugates for gene delivery. J Med Chem 45: 1817-1824.

9. Hosseinkhani H (2006) DNA nanoparticles for gene delivery to cells and tissue. I J Nanotech 3: 416-461.

10. Hosseinkhani H, Azzam T, Kobayashi H, Hiraoka Y, Shimokawa H, et al (2006) Combination of 3D tissue engineered scaffold and non-viral gene carrier enhance in vitro DNA expression of mesenchymal stem cells. Biomaterials 27: 4269-4278.

11. Hosseinkhani H, Azzam T, Tabata Y, Domb A (2004) Dextran-spermine polycation: an efficient nonviral vector for in vitro and in vivo gene transfection. Gene therapy 11: 194-203.

12. Alibolandi M, Abnous K, Sadeghi F, Ramezani M, Hosseinkhani H, et al. (2016) Folate Receptor-Targeted Multimodal Polymersomes for delivery of quantum dots and doxorubicin to breast adenocarcinoma: in vitro and in vivo Evaluation. Int J Pharm 500: 162-178.

13. Abedini F, Hosseinkhani H, Ismail M, Domb AJ, Omar AR, et al. (2012) Cationized Dextran Nanoparticles-Encapsulated CXCR4-siRNA
Enhanced Correlation between CXCR4 Expression and Serum ALP in Colorectal Cancer. Int J Nanomed 7: 4159-4168.

14. Mottaghitalab F, Shokrghozar MA, Farokhi M, Hosseinkhani H (2015) Silk fibrin nanoparticles as novel drug delivery systems. J Control Release 206: 161-176.

15. Yeo WY, Hosseinkhani H, Rahman SA, Rosli R, Domb AJ (2014) Safety Profile of Dextran-Spermine Gene Delivery Vector in Mouse Lungs. J Nanosci Nanotechnol 14: 3328-3336.

16. Hosseinkhani H, Abedini F, Ou KL, Domb AJ (2015) Polymers in Gene Therapy Technology. Polym Adv Technol 26: 198-211.

17. He WJ, Hosseinkhani H, Hong PD, Chiang CH, Yu DS (2013) Magnetic Nanoparticles for Imaging Technology. Int J Nanotec 10: 930-944.

18. Alibolandi M, Abnous K, Ramezani M, Hosseinkhani H, Hadizadeh $\mathrm{F}$ (2014) Synthesis of AS1411-Aptamer-Conjugated CdTe Quantum Dots with High Fluorescence Strength for Probe Labeling Tumor Cells. J Fluoresc 24: 1519-1529.

19. Hosseinkhani H, Hosseinkhani M (2009) Biodegradable polymer-metal complexes for gene and drug delivery. Curr Drug Saf 4: 79-83.

20. Hosseinkhani H, Hosseinkhani M, Chen Y R, Subramani K (2011) Innovative technology of engineering magnetic DNA nanoparticles for gene therapy. Int J Nanotec 8: 724-735.

21. Hosseinkhani M, Hosseinkhani H, Chen Y R, Subramani K (2011) In vitro physicochemical evaluation of DNA nanoparticles. Int J Nanotec 8: 736-748.

22. Amini R, Azizi Jalilian F, Abdullah S, Veerakumarasivam A, Hosseinkhani $\mathrm{H}$, et al. (2013) Dynamics of PEGylated-Dextran-Spermine Nanoparticles for Gene Delivery to Leukemic Cells. Appl Biochem Biotechnol 170: 841-853.

23. Hosseinkhani H, Chen YR, He W, Hong PD, Yu DS, et al. (2013) Engineering of Magnetic DNA Nanoparticles for Tumor-Targeted Therapy. J Nanopart Res 15: 1-10.

24. Hosseinkhani H, He WJ, Chiang CH, Yu DS, Hong PD, et al. (2013) Biodegradable Nanoparticles for Gene Therapy Technology. J Nanopart Res 15: 1-15.

25. Hosseinkhani H, Hosseinkhani M, Gabrielson NP, Pack DW Khademhosseini A, et al. (2008) DNA nanoparticles encapsulated in 3D tissue-engineered scaffolds enhance osteogenic differentiation of mesenchymal stem cells. J Biomed Mater Res A 85(1): 47-60.

26. Hosseinkhani $\mathrm{H}$, Inatsugu $\mathrm{Y}$, Hiraoka $\mathrm{Y}$, Inoue $\mathrm{S}$, Shimokawa $\mathrm{H}$, et al. (2005) Impregnation of plasmid DNA into three-dimensional scaffolds and medium perfusion enhance in vitro DNA expression of mesenchymal stem cells. Tissue Eng 11(9-10): 1459-1475.

27. Hosseinkhani H, Tabata Y (2006) Self-assembly of DNA nanoparticles with polycations for the delivery of genetic materials into cells. J Nanosci Nanotechnol 6(8): 2320-2328.

28. Hosseinkhani H, Aoyama T, Ogawa O, Tabata Y (2002) Liver targeting of plasmid DNA by pullulan conjugation based on metal coordination. J Control Release 83(2): 287-302.

29. Hosseinkhani H (2019) Nanomaterials in Advanced Medicine. New York: John Wiley \& Sons pp 224.

30. Saberianpour S, MoHeidarzadeh M, Geranmayeh MH, Hosseinkhani $\mathrm{H}$, Rahbarghazi R, et al. (2018) Tissue engineering strategies for the induction of angiogenesis using biomaterials. J Biol Eng 12(1): 38.

31. Abedini F, Ebrahimi M, Hosseinkhani H (2018) Technology of RNA interference in advanced medicine. MicroRNA 7(2): 74-84.

32. Abedini F, Ebrahimi M, Roozbehani AH, Domb AJ, Hosseinkhani H (2018) Overview on natural hydrophilic polysaccharide polymers in drug delivery. Polym Adv Technol 29 (10): 2564-2573. 
33. Abdullah S, Wendy Yeo WY, Hosseinkhani H, Mohsen Hosseinkhani, Ehab Masrawa, et al. (2010) Gene transfer into the lung by nanopartide dextran-spermine/plasmid DNA complexes. J Biomed Biotechnol 10: 284840.

34. Ghadiri M, Vasheghani Farahani E, Atyabi F, Kobarfard F, Hosseinkhani $\mathrm{H}$ (2017) In-vitro assessment of magnetic dextran-spermine nanoparticles for capecitabine delivery to cancerous cells. Iran J Pharm Res 16(4): 1320-1334.

35. Ghadiri M, Vasheghani Farahani E, Atyabi F, Kobarfard F, Mohamadyar Toupkanlou F, et al. (2017) Transferrin-conjugated magnetic dextranspermine nanoparticles for targeted drug transport across blood-brain barrier. J Biomed Mater Res A 105(10): 2851-2864.

36. Jain A, Hosseinkhani H, Domb AJ, Khan W (2015) Cationic Polymers for the Delivery of Therapeutic Nucleotides. In: Ramawat K, Mérillon JM (Eds) Polysaccharides. Springer International Publishing Switzerland pp 1969-1990.

37. He W, Hosseinkhani H, Mohammadinejad R, Ziba Roveimiab, Dueng Yuan Hueng, et al. (2014) Polymeric nanoparticles for therapy and imaging. Polym Adv Technol 25(11): 1216-1225.

38. Hosseinkhani H, Hong PD, Yu DS (2013) Self-assembled proteins and peptides for regenerative medicine. Chem Rev 113(7): 4837-4861.
39. Amini R, Jalilian FA, Abdullah S, A Veerakumarasivam, H Hosseinkhani, et al. (2013) Dynamics of PEGylated-dextran-spermine nanoparticles for gene delivery to leukemic cells. Appl Biochem Biotechnol 170(4): 841-853.

40. Khan W, Hosseinkhani H, Ickowicz D, Hong PD, Yu DS, et al. (2012) Polysaccharide gene transfection agents. Acta Biomater 8(12): 4224-4232.

41. Taheri MM, Vasheghani Farahani E, Hosseinkhani H, Shojaosadati SA, Soleimani M (2012) Fabrication and characterization of a new MRI contrast agent based on a magnetic dextran-spermine nanoparticle system. Iran Polym J 21: 239-251.

42. Amini R, Hosseinkhani H, Abdulamir A, Rosli R, Azizi Jalilian F (2012) Engineered smart biomaterials for gene delivery. Gene Ther Mol Biol 14: 72-86.

43. Hosseinkhani H, Hong PD, Yu DS, Yi Ru Chen, Diana Ickowicz, et al. (2012) Development of 3D in vitro platform technology to engineer mesenchymal stem cells. Int J Nanomedicine 7: 3035-3043.

44. Sharifzadeh G, Hosseinkhani H (2017) Biomolecule-Responsive Hydrogels in Medicine. Adv health Mate 6(24): 1700801.

45. Hosseinkhani H, Domb AJ (2019) Biodegradable polymers in genesilencing technology. Polym Adv Technol 30(10): 2647-2655.

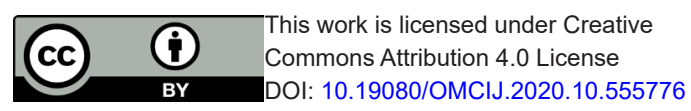

Your next submission with Juniper Publishers
will reach you the below assets
- Quality Editorial service
- Swift Peer Review
- Reprints availability
- E-prints Service
- Manuscript Podcast for convenient understanding
- Global attai nment for your research
- Manuscript accessibility in different formats
( Pdf, E-pub, Full Text, Audio)
- Unceasing customer service
Track the below URL for one-step submission
https://juniperpublishers.com/online-submission.php

